\title{
Southern African Customs Union Revenue, Public EXPENDITURES AND HIV/AIDS IN BLNS COUNTRIES
}

\author{
Harold Ngalawa \\ School of Accounting, Economics \& Finance, University of KwaZulu-Natal
}

Accepted: July 2013

\begin{abstract}
This study investigates how revenue from the Southern African Customs Union (SACU) common revenue pool affects efforts to contain HIVIAIDS in Botswana, Lesotho, Namibia and Swaziland (BLNS countries). Using a dataset for the BLNS countries covering the period 1990-2007 in annual frequency and a health production function, the study estimates a dynamic panel using the Arellano-Bond (1991) difference Generalised Method of Moments. The study results show that an increase in either SACU revenue or aggregate government expenditure increases HIV prevalence rates. Disaggregating the government expenditures into health and non-health outlays reveals that the health expenditure component decreases HIV prevalence rates. To be precise, the study finds that HIV prevalence rates decline when public health expenditures as a percentage of GDP and public health expenditures as a percentage of total government expenditures increase. It is argued, therefore, that the type of public expenditure is of consequence: public health expenditures decrease, while public non-health expenditures increase the HIV prevalence rates, with the ultimate direction of HIV prevalence rates determined by the dominant of the two effects.
\end{abstract}

Key words: government expenditure, customs union, health, HIV prevalence

JEL: H27, 51, I12

1

\section{Introduction}

Members of the Southern African Customs Union (SACU) - Botswana, Lesotho, Namibia, Swaziland and South Africa - deposit their customs and excise collections into a common revenue pool (CRP), which they share, using a formula that has evolved substantially since the establishment of the union more than a century ago. The revenue-sharing formula (RSF) currently in use was agreed upon following negotiations that started in 1994 and ended with a 2002 Agreement. Under this RSF, Botswana, Lesotho, Namibia and Swaziland (BLNS countries) combined get nearly half of the collections in the CRP, although their joint gross domestic product (GDP) is less than 10 per cent of SACU's aggregate GDP. Since total government expenditure is a component of GDP, the relatively small contribution by the BLNS countries to the aggregate GDP of SACU suggests that income from the CRP constitutes a considerable proportion of their total government revenue. In Swaziland, for instance, revenue from SACU accounts for over three quarters of government revenue, in Lesotho it constitutes nearly two thirds of fiscal revenue, and in Namibia it accounts for more than half of government revenue.

The SACU revenue, however, has been declining in recent years. In Namibia, SACU income is estimated to have dropped by 40 per cent in 2009/10 (van den Bosch, 2010), while in Lesotho the country's SACU revenue was expected to fall by 60 per cent in 2010/11 (Central Bank of Lesotho, 2010). In Swaziland, SACU income was projected to decline by 6 per cent in 2006/07, 6.4 per cent in 2009/10 and 12.5 per cent in 2010/11 (Government of Swaziland, 2008). Flatters and Stern (2005) predict that Swaziland's SACU revenue as a share of its GDP will decline from 17.6 per cent in 2005 to 9.4 per cent in 2020; Lesotho's share will go down to 12.6 per cent of GDP in 2020 from 21.5 per cent of GDP in 2005; while Namibia's and Botswana's shares will drop from 8.1 per cent and 5.1 per cent of GDP in 2005 to 4.4 per cent and 2.8 per cent of GDP respectively in 2020. For the BLNS countries 
combined, SACU revenue measured as a percentage of GDP is projected to decline from 14.4 per cent in 1994 to about 7.3 per cent in 2020 (Flatters \& Stern, 2005).

While SACU revenue has been falling, HIV has been spreading at an alarming rate in the southern African region. It is estimated that southern Africa has the highest HIV prevalence rates and the largest number of people in the world living with the virus (Avert, 2011; Avafia, 2004). At the beginning of the century, about 20 per cent of the entire population in the southern Africa region had already become infected with HIV (U.S. Agency for International Development (USAID), 2001). At present, Swaziland has the highest HIV prevalence rate in the world, with a national HIV prevalence of 26 per cent among the most sexually active age group (15-49 years) (Joint United Nations Programme on HIV/AIDS (UNAIDS), 2010). In Botswana, life expectancy at birth fell from 65 years in 1990-95 to less than 40 years in 2000-2005, a figure about 28 years lower than it would have been without HIV/AIDS (Avert, 2010).

What is the impact of the declining SACU revenue on HIV/AIDS in the BLNS countries? What are the implications for government expenditure? This study sets out to investigate these and other related issues. Using a health production function, the study shows that increasing either SACU revenue or aggregate government expenditure increases HIV prevalence rates. An increase in the health expenditure component of public outlays, however, decreases HIV prevalence rates. This finding suggests that the type of public expenditure is of consequence in the determination of HIV prevalence rates. Public health expenditures decrease while public non-health expenditures increase the HIV prevalence rates, with the ultimate direction of HIV prevalence rates being determined by the dominant of the two effects. The study also finds that increasing foreign aid reduces the prevalence rates of HIV. In the conclusion to the paper, it is argued that the declining SACU revenue, while putting pressure on fiscal budgets through the cost of care and treatment of people living with HIV/AIDS, may not adversely affect the fight against HIV prevention unless there is a slowdown in donor funding.
The rest of the paper is organised as follows. Section 2 is a summary of the SACU CRP operating framework and government revenue trends in the BLNS countries. An outline of the state of HIV/AIDS in the SACU member states follows in Section 3. Section 4 presents an econometric analysis of the relationship between the state of HIV/AIDS on the one hand, and SACU revenue and government expenditure on the other. The summary and conclusion conclude the paper in Section 5.

2

\section{The SACU common revenue pool and government revenue trends}

The Governments of Lesotho and Swaziland stand out among those of the SACU member states as the most dependent on SACU revenue. Lesotho's total receipts from the CRP accounted for 51.0 per cent of total government revenue (excluding grants) in 2001/02, before dropping slightly to 48.6 per cent in $2005 / 06$ and later increasing to 64.7 per cent in 2008/09 (see Table 1). In Swaziland, the figures are relatively higher, with the country's income from the CRP increasing from 54.1 per cent of total government revenue (excluding grants) in $2001 / 02$ to 68.5 per cent in $2005 / 06$ and 76.6 per cent in 2008/09. While Namibia's dependence on SACU revenue is relatively lower, it is estimated to have increased in recent years. The country's earnings from the CRP as a proportion of total government revenue rose to 51.2 per cent in $2008 / 09$ from 30.4 per cent in 2001/02.

SACU revenue expressed as a ratio of GDP in the BLNS countries combined took a downturn from 23.6 per cent in 1982 to 6.7 per cent in 1990 (see Figure 1). Thereafter, it stabilized to an extent until 2000/03, when the trend became upward, rising from 6.8 per cent in 2003 to 14.0 per cent in 2007, before entering another sharp downturn, reaching 11.6 per cent in 2008. Figure 1 clearly shows that, while SACU revenue as a ratio of GDP in the BLNS countries has been volatile, the trend for the period 1970-2008 has, on average, been downward. 
Table 1

SACU revenue

\begin{tabular}{|c|c|c|c|c|c|}
\hline \multicolumn{6}{|c|}{$2001 / 2002$} \\
\hline & Botswana & Lesotho & Namibia & Swaziland & RSA \\
\hline Receipts from SACU (R'million) & 2,622 & 1,438 & 2,641 & 1,503 & 9,897 \\
\hline$\%$ of total govt. revenue* & 12.8 & 51.0 & 30.4 & 54.1 & 3.9 \\
\hline$\%$ of common revenue pool & 13.8 & 7.6 & 13.9 & 7.9 & 56.7 \\
\hline \multicolumn{6}{|c|}{$2005 / 2006$} \\
\hline & Botswana & Lesotho & Namibia & Swaziland & RSA \\
\hline Receipts from SACU (R'million) & 4,008 & 1,984 & 3,228 & 2,795 & 13,027 \\
\hline$\%$ of Total govt. revenue* & 12.1 & 48.6 & 25.1 & 68.5 & 4.4 \\
\hline$\%$ of Common revenue pool & 14.0 & 6.8 & 11.4 & 9.2 & 58.5 \\
\hline \multicolumn{6}{|c|}{$2008 / 2009$} \\
\hline & Botswana & Lesotho & Namibia & Swaziland & RSA \\
\hline Receipts from SACU (R'million) & 9,473 & 4,901 & 8,502 & 6,009 & 15,220 \\
\hline$\%$ of Total govt. revenue* & NA & 64.66 & 51.22 & 76.59 & 3.3 \\
\hline$\%$ of Common revenue pool & 21.5 & 11.1 & 19.3 & 13.6 & 34.5 \\
\hline
\end{tabular}

${ }^{*}$ Excludes grants

Source: Flatters \& Stern, 2005; Government of South Africa, 2010; author's own calculations

Figure 1

SACU revenue as a ratio of GDP in BLNS countries (1970-2008)

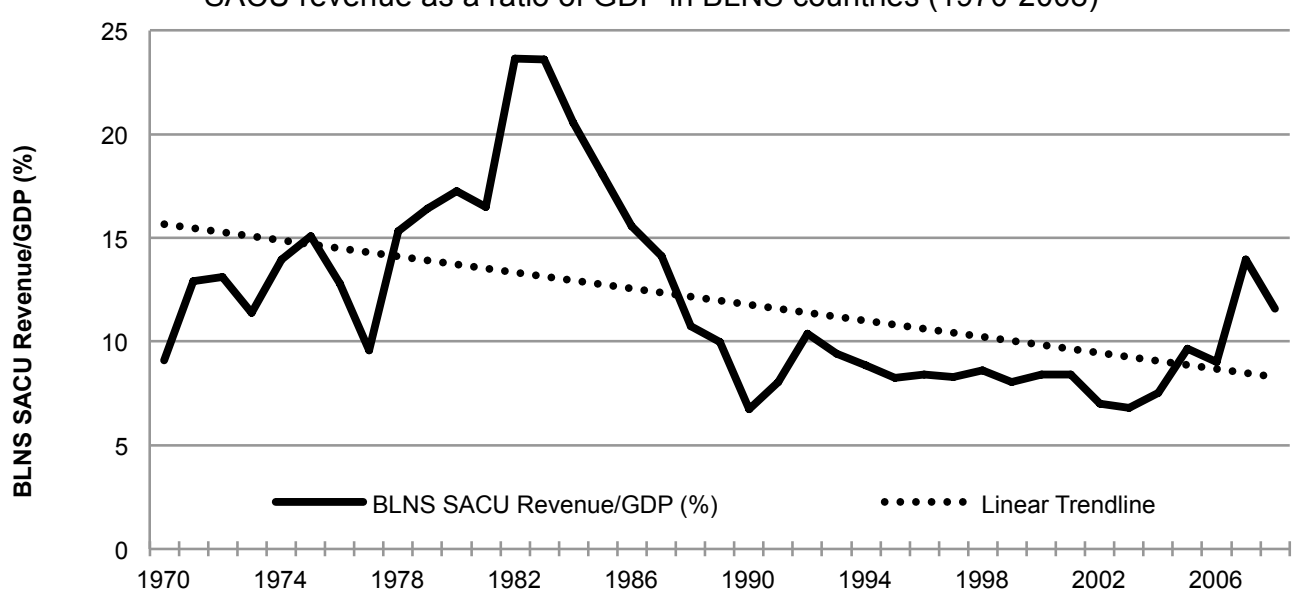

Source: South African Reserve Bank, World Bank World Development Indicators and author's own calculations

Current data from the respective BLNS countries show that the recent decline in SACU revenue is continuing and is likely to maintain the same path. The Central Bank of Lesotho (2010) reports that the country's SACU revenue declined by 60 per cent in 2010/11 owing to the global recession, which led to a decline in imports worldwide, including those of SACU member countries. Projected SACU revenues (expressed as a ratio of GDP) in the Lesotho Government Budget show a steady decline from 36.1 per cent in
$2009 / 10$ to 13.1 per cent in $2010 / 11$ and 9.3 per cent in 2011/12 (Government of Lesotho, 2009). In Swaziland, SACU receipts declined by 6 per cent in 2006/07 and went up by 13 per cent in the following fiscal year, before dropping by 6.4 per cent and 12.5 per cent in 2009/10 and 2010/11 respectively (Government of Swaziland, 2008). A similar trend has been recorded in Namibia, where SACU revenues as a ratio of GDP fell from 12.0 per cent in 2006 to 8.2 per cent in 2008 . 
The decline in SACU income has been projected to advance in line with the general trend observed previously. Flatters and Stern (2005) predict that Swaziland's SACU revenue as a share of its GDP will decline from 17.6 per cent in 2005 to 9.4 per cent in 2020;
Lesotho's share will fall to 12.6 per cent of GDP in 2020 from 21.5 per cent of GDP in 2005, while Namibia's and Botswana's shares will drop from 8.1 per cent and 5.1 per cent of GDP in 2005 to 4.4 per cent and 2.8 per cent of GDP respectively in 2020 (see Table 2).

Table 2

SACU revenues as a share of GDP

\begin{tabular}{|l|r|r|r|r|}
\multicolumn{1}{c|}{} & $\mathbf{1 9 9 4}$ & $\mathbf{2 0 0 2}$ & $\mathbf{2 0 0 5}$ & $\mathbf{2 0 2 0}$ \\
\hline Botswana & 8.0 & 4.5 & 5.1 & 2.8 \\
\hline Lesotho & 28.0 & 19.8 & 21.5 & 12.6 \\
\hline Namibia & 7.7 & 7.8 & 8.1 & 4.4 \\
\hline Swaziland & 13.7 & 12.9 & 17.6 & 9.4 \\
\hline BLNS & 4.4 & 11.3 & 13.1 & 7.3 \\
\hline RSA & 1.6 & 1.2 & 0.9 & 0.8 \\
\hline
\end{tabular}

Source: Flatters \& Stern (2005)

3

\section{HIV/AIDS in BLNS countries}

Southern Africa continues to carry a heavy HIV/AIDS burden. All five SACU member states exhibit national HIV/AIDS prevalence rates at epidemic levels (see Table 3 for key HIV/AIDS figures in the BLNS countries). ${ }^{1}$ Recent studies show that HIV/AIDS prevalence in the region has stabilized, although at a high and unsustainable level (see, for example, UNAIDS, 2009). While the epidemic may have stabilised, there are as yet no solutions for reversing the epidemic by reducing incidence, which remains extremely high among females, especially those who are younger (see HSRC, 2008). Whether the incidence is declining among some groups and increasing among teenagers remains an open question. ${ }^{2}$ It is therefore expected that fiscal budgetary implications for the cost of care and treatment for people living with HIV and AIDS and support of those left affected by it (such as AIDS orphans) will continue to exert pressure on already tight fiscal budgets.

Table 3

HIVIAIDS in BLNS countries: key indicators

\begin{tabular}{|l|c|c|c|c|c|}
\cline { 2 - 6 } \multicolumn{1}{c|}{} & Year & Botswana & Lesotho & Namibia & Swaziland \\
\hline National HIV prevalence (percent) & $2007 / 08$ & 23.90 & 23.20 & 15.30 & 26.10 \\
\hline AIDS deaths & 2007 & 11,000 & 18,000 & 5,100 & 10,000 \\
\hline AIDS orphans & 2007 & 95,000 & 110,000 & 66,000 & 56,000 \\
\hline ARV treatment coverage (percent) & $2007 / 08$ & 79 & 26 & 88 & 42 \\
\hline Govt. health expenditure per capita (US\$) & 2006 & 815 & 98 & 261 & 300 \\
\hline Life expectancy (female) & 2007 & 56 & 47 & 61 & 49 \\
\hline Life expectancy (male) & 2007 & 56 & 43 & 58 & 47 \\
\hline
\end{tabular}

Source: Kaiser Family Foundation, 2010

Currently, the United States President's Emergency Plan for AIDS Relief (PEPFAR) and the Global Fund for AIDS, Tuberculosis and Malaria (the Global Fund) provide most financial support for treatment in Lesotho, Namibia and Swaziland. However, the availability of funding for treating people in need of antiretroviral treatment (ART) in the near future is not secure. PEPFAR's 2009-2014 plan shows a slowdown in the rate of enrollment for new patients (PEPFAR, 2009), while the Global Fund continues to face gaps in funding (Médecins sans Frontières (MSF), 2010). With major donors increasingly reluctant to become 
locked into long-term funding for AIDS, the financial responsibility falls on these countries at a time when revenue injections from SACU are decreasing.

Escalating AIDS-related deaths have reduced average life expectancy and altered demographic patterns in southern Africa. Population growth projections for 2008-2050 show increases for Botswana (29 percent) and Namibia (3 percent), and declines in Lesotho (11 percent) and Swaziland (33 percent) (Population Reference Bureau, 2008). The world average for less developed countries (excluding China) over the same period is a 59 per cent increase. AIDS-related deaths and the absence of descendants from mothers who have died of AIDS are the primary factors that have contributed to the slow population growth in the BLNS countries.

The contribution of government funding relative to donor and private-sector funding for HIV/AIDS programs differs significantly across the BLNS countries. It varies from 18.7 per cent in Lesotho (2006) to 91.3 per cent in Botswana (2006). In Namibia and Swaziland, public expenditures are 50.8 per cent (2007) and 39.8 per cent (2006) of total expenditures on HIV/AIDS respectively (see Table 4). This shows that Lesotho is the most dependent on donors and the private sector in funding HIV/AIDS initiatives, followed by Swaziland and Namibia, while Botswana is the most reliant on public expenditures.

Table 4

Public and donor / private sector spending on HIVIAIDS in BLNS countries

\begin{tabular}{|l|c|c|c|c|c|c|}
\hline \multicolumn{1}{|c}{ Country } & \multicolumn{3}{|c}{$\begin{array}{c}\text { Total spending on HIVIAIDS) } \\
\text { (US\$ million) }\end{array}$} & \multicolumn{3}{c|}{ Share of public spending in total spending } \\
\hline & $\mathbf{2 0 0 5}$ & $\mathbf{2 0 0 6}$ & $\mathbf{2 0 0 7}$ & $\mathbf{2 0 0 5}$ & $\mathbf{2 0 0 6}$ & $\mathbf{2 0 0 7}$ \\
\hline Botswana & 206.94 & 143.41 & 229.46 & 79.25 & 91.26 & 88.82 \\
\hline Lesotho & NA & 24.436 & NA & NA & 18.69 & NA \\
\hline Namibia & 79.122 & NA & 130.5 & 48.73 & NA & 50.80 \\
\hline Swaziland & NA & 49.113 & NA & NA & 39.83 & NA \\
\hline
\end{tabular}

Source: UNAIDS, 2009

\section{4 \\ Empirical framework}

\subsection{Estimation model}

An improvement in health status increases lifeexpectancy and enhances the quality and productivity of human capital, thereby improving on welfare. The economic theory of consumer choice therefore suggests that an individual seeks to maximise utility by attaining the highest health status possible given his/her cost constraint. Accordingly, the framework for the analysis of the production of health is rooted in the economic theory of consumer choice.

According to human capital theory, health is a product of a household's production process in which an individual desires a certain level of health at any given point in his life (Desai, 1987). To produce this level of health, the individual employs inputs of market goods (ibid), including medical care, income and education. It is assumed that the availability of inputs in health production is dependent on financial resources. It is further postulated that, at the aggregate level in a developing country, the financial resources accounting for the inputs in the health production function come largely from either state resources or foreign aid. Accordingly, the state of health at the aggregate level is given by:

$$
\text { health }_{i t}=f\left(\text { aid }_{i t}, \text { gov }_{i t} ; \mu_{i t}\right)
$$

where health is the state of health; aid is foreign aid; gov is government expenditures; $i$ $(\forall i=1,2,3,4)$ is a country counter; $t \quad(\forall$ $t=1, \ldots, T)$ is a time index for a total of $n=4 T$ observations; and $\mu_{i t}$ is an error term. Government expenditures are classified into aggregate government expenditures (govexp) and SACU revenue (sacur) among the SACU member states. Therefore the empirical production function is given by:

$$
\begin{aligned}
& \text { hivprev }_{i t}= \\
& a_{i} \sum_{k}^{n} \delta_{k} \text { hivprev }_{i t-k}+\sum_{j}^{m} \beta_{j} X_{i t-j}+\mu_{i t}
\end{aligned}
$$


where hivprev is HIV prevalence rate, a proxy for the state of health; $X_{i t}$ is an $(n \times 1)$ vector of variables where $X_{i t}:=\{$ aid, govexp, sacur $\}$; $\delta$ and $\beta$ are coefficients; and $C$ is a constant. The objective is to produce low levels of HIV prevalence. The theoretical expectation is that an increase in foreign aid and SACU revenue or government expenditure will cause a decline in the HIV prevalence rate, either directly (for example, through condom distribution and provision of antiretroviral therapy for the prevention of mother to child transmission of HIV) or indirectly through investments in HIV awareness and prevention campaigns that have been shown to be effective in reducing HIV transmission and risky-sexual behaviour. Examples of this would be keeping girls in school, economic empowerment of young women to stem inter-generational sex, empowerment of women generally (including commercial sex workers) and tackling behavioural drivers of the epidemic, such as multiple concurrent partnerships. The error term, $\mu_{i t}$, is defined as:

$$
\mu_{i t}=e_{i}+\varepsilon_{i t}
$$

where $e_{i}$ affects all observations for crosssectional unit $i$, and $\varepsilon_{i t}$ affects only observation it (Davidson \& MacKinnon, 2004). It is assumed that the shocks $e_{i}$ are independent across all $i$ and the shocks $\varepsilon_{i t}$ are independent across all cross-sections $i$ and time periods $t$. It is further assumed that the shocks $e_{i}$ are random and $\operatorname{Var}\left(\mu_{i t}\right)=\sigma_{e}^{2}+\sigma_{v}^{2} ; \operatorname{Cov}\left(\mu_{i t}, \mu_{j s}\right)=$ 0 ; and $\operatorname{Cov}\left(\mu_{i t}, \mu_{i s}\right)=\sigma_{e}^{2}$.

There are several estimation problems that may arise from the formulation in equation (2). First is a possible endogeneity problem. A priori, it is reasonable to presume that the HIV epidemic has triggered increases in foreign aid and government spending. Accordingly, the regressors may be correlated with the error term. In addition, time-invariant country characteristics like geography and demographics may be correlated with the explanatory variables. Furthermore, owing to the presence of the lagged dependent variable among the regressors, both random- and fixed-effects approaches would render the estimates inconsistent in line with the Nickel bias (Nickel, 1981). To avoid these problems, the model is estimated using the Arellano-Bond (1991) difference Generalised Method of Moments (GMM). This dynamic panel modeling technique was first proposed by Holtz-Eakin, Newey and Rosen (1988) and, inter alia, it limits the tendency of spurious regressions and wrong inferences common in static models. The difference GMM uses firstdifferences that transform equation (2) into:

$$
\begin{aligned}
& \Delta \text { hivprev }_{i t}=a_{i} \sum_{k}^{n} \delta_{k} \text { shivprev } \text { it }-k+ \\
& \sum_{j}^{m} \beta_{j} \Delta X_{i t-j}+\Delta \mu_{i t}
\end{aligned}
$$

which effectively removes the fixed countryspecific effect because it does not vary with time (see Mileva, 2007). That is:

$$
\Delta \mu_{i t}=\Delta e_{i}+\Delta \varepsilon_{i t}=\Delta \varepsilon_{i t}
$$

Since SACU revenue is part of government revenue and is thus used for government outlays, a high degree of correlation is expected between sacur and govexp. A zero-order correlation matrix (see Table 5) confirms that sacur and govexp are highly correlated with a correlation coefficient of 0.6684 , which is statistically significant at 1 percent. Accordingly, these

\begin{tabular}{|c|c|c|c|c|}
\hline & HIV prevalence & Foreign aid & SACU revenue & Govt. expenditure \\
\hline $\begin{array}{l}\text { HIV prevalence } \\
\text { Observations }\end{array}$ & $\begin{array}{l}1.0000 \\
72\end{array}$ & & & \\
\hline $\begin{array}{l}\text { Foreign aid } \\
\text { Observations }\end{array}$ & $\begin{array}{l}-0.5293^{* * *} \\
(0.0000) \\
72\end{array}$ & $\begin{array}{l}1.0000 \\
72\end{array}$ & & \\
\hline $\begin{array}{l}\text { SACU revenue } \\
\text { Observations }\end{array}$ & $\begin{array}{l}0.5055^{\star \star \star} \\
(0.0000) \\
71\end{array}$ & $\begin{array}{l}-0.0688 \\
(0.5687) \\
71\end{array}$ & $\begin{array}{l}1.0000 \\
71\end{array}$ & \\
\hline $\begin{array}{l}\text { Govt. expenditure } \\
\text { Observations }\end{array}$ & $\begin{array}{l}0.3446^{\star * *} \\
(0.0030) \\
72\end{array}$ & $\begin{array}{l}0.1461 \\
(0.2208) \\
72\end{array}$ & $\begin{array}{l}0.6684^{* \star *} \\
(0.0000) \\
71\end{array}$ & $\begin{array}{l}1.0000 \\
71\end{array}$ \\
\hline
\end{tabular}
variables are not used in the same equation.

Table 5

Zero-order correlation matrix

$P$-Values given in parenthesis

${ }^{* * *},{ }^{* *}$, and ${ }^{*}$ denote statistical significance at 1, 5 and 10 percent, respectively. 


\subsection{Data and data sources}

The study is carried out using a panel dataset of Botswana, Lesotho, Namibia and Swaziland, covering the period 1990-2007 in annual frequency. The choice of the study period was dictated by the availability of data. The variable hivprev is measured by the total prevalence rate of HIV among the sexually active population age (15-49 years); aid is per capita foreign aid measured in United States (US) dollars; govexp is general government final consumption expenditure measured in US dollars; and sacur is revenue from the SACU CRP, also measured in US dollars. All variables except hivprev are expressed in natural logarithm.

Data for HIV prevalence rates, foreign aid and government expenditure was obtained from the World Development Indicators online, a World Bank database for economic and demographic indicators. SACU revenue data, on the other hand, was sourced from the South
African Reserve Bank, annual reports of the SACU Secretariat and the Central Bank of Lesotho. Additional data was collected from publications by the South African Revenue Service and National Treasury, and the BLNS countries' national budget documents, as well as central bank quarterly financial and economic reports.

Prior to analysis, the data was tested for stationarity, using the Im, Pesaran and Shin (IPS) procedure for panel unit root tests. Optimal lag length is selected by minimising the Schwarz Bayesian information criteria. Table 6 presents the unit root test results. The table indicates that, except for hivprev, which is integrated of order zero, all variables in the model are integrated of order 1, suggesting the presence of unit roots in the data, which may lead to spurious regressions and wrong inferences. This underscores the merit of using the Arellano-Bond (1991) difference GMM estimation method.

Table 6

$\mathrm{Im}$, Pesaran and Shin panel unit root test results

\begin{tabular}{|l|c|c|c|c|}
\hline \multicolumn{1}{|c|}{ Variable } & Statistic & P-Value & $\begin{array}{c}\text { Level of } \\
\text { significance }\end{array}$ & $\begin{array}{c}\text { Order of } \\
\text { integration }\end{array}$ \\
\hline HIV prevalence & -14.7046 & 0.0000 & $1 \%$ & 0 \\
\hline Foreign aid & -6.0360 & 0.0000 & $1 \%$ & 1 \\
\hline SACU revenue & -3.2863 & 0.0005 & $1 \%$ & 1 \\
\hline Govt. Expenditure & -3.8572 & 0.0001 & $1 \%$ & 1 \\
\hline
\end{tabular}

\subsection{Estimation results}

Table 7 presents the Arellano-Bond (1991) difference GMM estimation results of equation (4) for regressions of foreign aid and government expenditure on HIV prevalence rates (Regression 1) and foreign aid and SACU revenue on HIV prevalence rates (Regression $2)$. Both regressions show that foreign aid reduces the prevalence rates of HIV. The foreign aid coefficient is, in each case, statistically significant (at 10 per cent in Regression 1 and 5 per cent in Regression 2) with the expected negative sign, suggesting that an increase in foreign aid has the effect of reducing HIV prevalence rates. Consistent in both regressions, a 1 per cent increase in foreign aid is associated with a decline in HIV prevalence rates by about a quarter of a per cent $(0.14$ per cent in Regression 1 and 0.18 per cent in Regression 2). This finding confirms that donor aid has a significant impact on reducing the impact of HIV/AIDS in the BLNS countries.

Both government expenditure and SACU revenue have positive signs and are statistically significant at 1 percent, indicating that HIV prevalence rates in the BLNS countries increase with an increase in either government expenditure or SACU revenue. This is a surprising finding. Given this positive relationship between aggregate public expenditures and HIV prevalence rates, a similar relationship between the non-health component of public expenditures and HIV prevalence rates can be expected. However, it is unlikely to be the same for the health expenditure component. It is hypothesised that there is an inverse relationship between public health expendi- 
tures and HIV prevalence rates. To test this hypothesis, total government expenditure in Regression 1 is replaced with public health expenditure as a percentage of GDP (Regression 3), public health expenditure as a percentage of total government expenditure (Regression 4) and public health expenditure as a percentage of total health expenditure (Regression 5). The only constraint is the lack of adequate observations. At the time of the study, only 20 observations were available for these variables, covering the period 20022006. The estimation results of Regressions 3, 4 and 5 are presented in Table 8 . The negative relationship between foreign aid and HIV prevalence, observed previously, shows up again in all equations.

Table 7

Estimation results

\begin{tabular}{|l|c|c|}
\hline \multicolumn{3}{|c|}{ Dependent variable: HIV prevalence rate } \\
\hline Variable & Regression 1 & Regression 2 \\
\hline HIV prevalence (-1) & $1.7237^{\star * *}$ & $1.7488^{* * *}$ \\
& $(0.02513)$ & $(0.0281)$ \\
\hline HIV prevalence (-2) & $-0.8050^{\star * *}$ & $-0.8298^{* * *}$ \\
& $(0.0250)$ & $(0.02850)$ \\
\hline Foreign aid (-2) & $-0.1421^{*}$ & $-0.1764^{\star *}$ \\
& $(0.0728)$ & $(0.0778)$ \\
\hline Govt. expenditure & $0.3562^{* * *}$ & \\
& $(0.1080)$ & $0.2411^{* * *}$ \\
\hline SACU revenue & & $(0.0697)$ \\
\hline Constant & & $0.7076^{*}$ \\
& $(0.6929)$ & $(0.4155)$ \\
\hline Wald $\chi^{2}(4)$ & 70008.61 & 68607.21 \\
\hline Prob $>\chi^{2}$ & 0.0000 & 0.0000 \\
\hline
\end{tabular}

Standard errors in parenthesis

***, ** and * denote statistical significance at 1, 5 and 10 percent, respectively.

Table 8

Estimation results

\begin{tabular}{|c|c|c|c|}
\hline \multicolumn{4}{|c|}{ Dependent variable: HIV prevalence rate } \\
\hline Variable & Regression 3 & Regression 4 & Regression 5 \\
\hline HIV prevalence (-1) & $\begin{array}{l}0.8354^{* * *} \\
(0.0660)\end{array}$ & $\begin{array}{l}0.7517^{* * *} \\
(0.0769)\end{array}$ & $\begin{array}{l}0.8692^{* * *} \\
(0.0595)\end{array}$ \\
\hline Foreign Ald & $\begin{array}{l}-0.2776^{\star \star \star} \\
(0.1032)\end{array}$ & $\begin{array}{l}-0.2355^{\star *} \\
(0.1093)\end{array}$ & $\begin{array}{l}-0.2990^{* * *} \\
(0.0891)\end{array}$ \\
\hline $\begin{array}{l}\text { Public health expenditure } \\
(\% \text { of } G D P)\end{array}$ & $\begin{array}{l}-0.5228^{* *} \\
(0.2068)\end{array}$ & & \\
\hline $\begin{array}{l}\text { Public health expenditure/ } \\
\text { (\% of total government expenditure) }\end{array}$ & & $\begin{array}{l}-0.6746^{* * *} \\
(0.2273)\end{array}$ & \\
\hline $\begin{array}{l}\text { Public health expenditure/ } \\
\text { (\% of total health expenditure) }\end{array}$ & & & $\begin{array}{c}0.2270 \\
(0.3543)\end{array}$ \\
\hline Constant & $\begin{array}{l}5.0405^{\star \star *} \\
(1.4615)\end{array}$ & $\begin{array}{l}7.4878^{* * *} \\
(1.8835)\end{array}$ & $\begin{array}{c}2.7437 \\
(2.2002)\end{array}$ \\
\hline Wald $\chi^{2}(4)$ & 187.05 & 175.42 & 240.90 \\
\hline Prob $>\chi^{2}$ & 0.0000 & 0.0000 & 0.0000 \\
\hline
\end{tabular}

Standard errors given in parentheses

${ }^{* \star *},{ }^{* *}$ and * denote statistical significance at 1, 5 and 10 percent, respectively. 
However, an inverse relationship is now observed between HIV prevalence and public health expenditures as a percentage of GDP (Regression 3) and public health expenditures as a percentage of total government expenditures (Regression 4). In both cases, the coefficients are statistically significant (at 5 per cent in Regression 3 and 1 per cent in Regression 4). The coefficient of public health expenditure as a percentage of total health expenditure (Regression 5), on the other hand, is statistically insignificant.

This inverse relationship between public health expenditures and HIV prevalence and the positive relationship between aggregate government expenditures and the HIV prevalence established earlier suggests that public nonhealth expenditures increase HIV prevalence. It follows, therefore, that the type of public expenditure matters in the determination of HIV prevalence rates. Since public health expenditures decrease while public non-health expenditures are deemed to increase HIV prevalence rates, the ultimate direction of HIV prevalence rates is likely to be determined by the dominant of the two effects. In this case, public non-health expenditures clearly dominate over public health expenditures in the determination of HIV prevalence.

Public non-health expenditures can be compartmentalised into recurrent and development expenditures. A number of studies have found that development expenditures are strongly associated with improvements in the state of health (see, for example, Filmer \& Pritchett, 1999; World Bank, 1993; Caldwell, 1986). If this applies to the BLNS countries as well, the positive relationship between aggregate public expenditures and HIV prevalence rates must be the reflection of a positive relationship between recurrent public non-health expenditures and HIV prevalence rates.

In all the estimation results, Wald test statistics have been reported to provide a test for the hypothesis that all coefficients except the intercept term are equal to zero in each model. In all cases, the Wald chi square strongly rejects the hypothesis that the conditional mean is constant and independent of the explanatory variables.

\section{5}

\section{Summary and conclusion}

Against a background of HIV/AIDS at epidemic levels and declining SACU revenue in BLNS countries, this study investigates the relationship between HIV prevalence rates on the one hand, and both SACU revenue and government expenditure on the other. Using a health production function, the study finds that HIV prevalence rates increase with increasing SACU revenue or government expenditure. Isolating public health expenditures from the pool of aggregate government expenditures, it is found that HIV prevalence rates decline when public health expenditures increase, in concurrence with a priori theoretical expectations. Consistent results are obtained in separate experiments with different measures of health expenditures (public health expenditure as a percentage of GDP and public health expenditure as a percentage of total government expenditure).

The observed positive relationship between aggregate government expenditures and HIV prevalence and the inverse relationship between public health expenditures and HIV prevalence suggests that public non-health expenditures increase HIV prevalence rates. Since public health expenditures decrease, while public nonhealth expenditures are deemed to increase HIV prevalence rates, the ultimate direction of HIV prevalence rates is likely to be determined by the dominant of the two effects, in this case, public non-health expenditures.

The public non-health expenditures can be grouped into recurrent and development expenditures. A number of studies have established that development expenditures are strongly associated with improvements in the state of health. Assuming this applies to the BLNS countries as well, it must be that the positive relationship between aggregate public expenditures and HIV prevalence rates is the reflection of a positive relationship between recurrent public non-health expenditures and HIV prevalence rates.

It is expected that the declining SACU revenue will not worsen the state of HIV/AIDS in the BLNS countries unless the proportion of public non-health expenditures declines significantly, while the share of health expen- 
ditures in the government budget increases and the SACU revenue continues to decline thereafter. While the decrease in SACU revenue is a concern, there is a deeper problem: inadequate public resources are allocated to the health sector relative to non-health activities. More specifically, it can be inferred that recurrent public expenditures in the non-health sector are too high relative to recurrent public health expenditures. If the BLNS countries were to start allocating fewer public resources to the latter, a direct relationship between SACU revenue and HIV prevalence would probably appear. That is, increasing SACU revenue or government expenditure would be accompanied by declining HIV prevalence rates. Should SACU revenue continue to decline thereafter, the state of HIV/AIDS would in all likelihood worsen.

\section{Acknowledgements}

The author acknowledges financial support from Economic Research Southern Africa (ERSA) and University of KwaZulu-Natal's Health Economics and HIV/AIDS Research Division (HEARD). The author also acknowledges very useful comments by Khaled Ahmed of HEARD.

\section{Endnotes}

1 HIVIAIDS is regarded as having reached epidemic levels when prevalence rates peak above 10 percent.

2 The author is grateful to an anonymous referee for bringing this point out.

\section{References}

ARELLANO, M. \& BOND, S. 1991. Some tests of specification for panel data: Monte Carlo evidence and an application to employment equations. Review of Economic Studies, 58 (April 1991):277-297.

AVAFIA, T. 2004. The potential impact of US-SACU FTA negotiations on public health in southern Africa, Tralac Working Paper No. 6/2004.

AVERT. 2010. HIV and AIDS in Botswana. Available at: http://www.avert.org/aidsbotswana.htm [accessed 11-05-2011]

AVERT. 2011. HIV and AIDS in Swaziland. Available at: http://www.avert.org/aidsswaziland.htm [accessed 07-02- 2011].

CALDWELL, J. 1986. Routes to low mortality in poor countries. Population and Development Review, 12(2):171-220.

CENTRAL BANK OF LESOTHO. 2010. Lesotho's budget speech for the fiscal year 2010/11, Central Bank of Lesotho Economic Review, (February):1-8.

DAVIDSON, R. \& MACKINNON, J. 2004. Econometric theory and methods, New York: Oxford University Press.

DESAI, S. 1987. The estimation of the health production function for low-income working men. Medical Care, 25(7):604-615.

FILMER, D. \& PRITCHETT, L. 1999. The impact of public spending on health: Does money matter? Social Science \& Medicine, 49 (1999):1309-1323.

FLATTERS, F. \& STERN, M. 2005. Implementing the SACU revenue-sharing formula: Customs revenues. Policy brief prepared for the South African National Treasury, Pretoria.

GOVERNMENT OF LESOTHO. 2009. Budget speech for the fiscal year 2009/2010. Available at: http://www.lesotho.gov.ls/articles/2009/Budget_Speech_2009-10.pdf [accessed 28-3-2011].

GOVERNMENT OF SOUTH AFRICA. 2010. 2009 Tax statistics. A joint publication of the National Treasury and the South African Revenue Service. Available at: www.sars.gov.za [accessed 28-3- 2011]. GOVERNMENT OF SWAZILAND. 2008. Budget speech 2008. Available at: http://www.gov.sz/default. aspx?pid=1814\&stepid=1\&oid=1821 [accessed 23-9-2010].

HOLTZ-EAKIN, D., NEWEY, W. \& ROSEN, H.S. 1988. Estimating vector autoregressions with panel data. Econometrica, 56:1371-1395. 
HUMAN SCIENCE RESEARCH COUNCIL (HSRC). 2008. Incidence, behaviour and communication survey, 2008: A Turning Tide Among Teenagers? Cape Town: HSRC Press. Available at: http://www.mrc. ac.za/pressreleases/2009/sanat.pdf [accessed 18-02-2014].

JOINT UNITED NATIONS PROGRAMME ON HIV/AIDS. 2010. UNAIDS report on the global AIDS epidemic 2010. Available at: http://www.unaids.org/documents/20101123_GlobalReport_em.pdf [accessed 28-3-2011].

JOINT UNITED NATIONS PROGRAMME ON HIV/AIDS. 2009. Aids epidemic update 2009 [Online]. Available at: http://data.unaids.org/pub/Report/2009/jc1700_epi_update_2009_en.pdf [accessed 28-3-2011]. KAISER FAMILY FOUNDATION. 2010. Global health facts. Available at: http://www.kff.org/ [accessed 28-3-2011].

MÉDECINS SANS FRONTIÈRES. 2010. No time to quit: HIV/AIDS treatment gap widening in Africa, Brussels: Médecins Sans Frontières.

MILEVA, E. 2007. Using Arellano-Bond dynamic panel GMM estimators in stata. Available at: http://www.fordham.edu/economics/mcleod/Elitz-UsingArellano\%E2\%80\%93BondGMMEstimators.pdf [accessed on 23-2-2013].

MSF. 2010. See Médecins Sans Frontières.

NICKEL, S. 1981. Biases in dynamic models with fixed effects. Econometrica, 49(6):1417-1426.

PEPFAR. 2009. See President's Emergency Plan for AIDS Relief.

POPULATION REFERENCE BUREAU. 2008. World population data sheet, Washington DC: Population Reference Bureau.

PRESIDENT'S EMERGENCY PLAN FOR AIDS RELIEF. 2009. The US President's Emergency Plan for HIV/AIDS: Five Year Strategy. Available at: http://www.pepfar.gov/documents/organization/133035.pdf [accessed 28-3- 2011]. UNAIDS. 2010. See Joint United Nations Programme on HIV/AIDS.

UNAIDS. 2009. See Joint United Nations Programme on HIV/AIDS.

USAID. 2001. See U.S. Agency for International Development.

U.S. AGENCY FOR INTERNATIONAL DEVELOPMENT. 2001. HIV/AIDS in southern Africa:

Background, projections, impacts, and interventions. Available at: http://www.policyproject.com/pubs/ countryreports/SoAf1001.pdf [accessed on 7-2-2011].

VAN DEN BOSCH, S. 2010. Unexpected low customs revenue in SACU causes budget shortfalls. Available at: http://ipsnews.net/news.asp?idnews=50700 [accessed on 11-6- 2010].

WORLD BANK. 1993. World Development Report 1993: Investing in health, New York: Oxford University Press. 